\title{
CLINICAL OUTCOMES IN THE FIRST YEAR OF LIFE OF PREMATURE INFANTS
}

\author{
Cristiane Raupp NUNES ${ }^{\mathrm{a}}$, Leticia Gabriel ABDALA ${ }^{\mathrm{b}}$, \\ Mariur Gomes BEGHETTO ${ }^{c}$
}

\begin{abstract}
The aim of this retrospective cohort study was to investigate clinical outcomes of the first year of life of premature infants discharged from the Neonatal Intensive Care Unit (NICU) based on mortality and readmission data, and the motor development of the children. The sample consisted of 170 children with gestational age under 37 weeks and who survived hospitalization in neonatal intensive care unit (NICU). Data were collected from medical records, the hospital IT system and telephone interview with the caregiver. The authors found 100\% survival during the study period and that $39.4 \%$ of the infants were often readmitted (26.5\%) due to respiratory conditions. Their development was considered as expected, when using the corrected age. In conclusion, the premature infants from this study showed good clinical evolution of the proposed observation.
\end{abstract}

Descriptors: Intensive care units, neonatal. Infant, premature. Infant, very low birth weight.

\section{RESUMO}

O estudo investigou desfechos clínicos do primeiro ano de vida de prematuros egressos da Unidade de Terapia Neonatal (UTIN), a partir de dados da mortalidade, reinternação e do desenvolvimento motor destas crianças. Tratou-se de uma pesquisa de coorte retrospectiva. A amostra foi composta 170 de crianças, com idade gestacional menor que 37 semanas, que sobreviveram à internação na UTIN. Os dados foram coletados dos prontuários, do sistema informatizado do hospital e de entrevista telefồnica com o responsável pela criança. Observou-se 100\% de sobrevida no período estudado, 39,4\% dos $R N$ apresentaram reinternações hospitalares, frequentemente (26,5\%) por afecções respiratórias. Quanto ao desenvolvimento, verificou-se que, utilizando-se a idade corrigida, foi considerado dentro do esperado. Ao término deste estudo, concluiu-se que os prematuros dos estudos apresentaram boa evolução clínica de observação proposta.

Descritores: Unidades de terapia intensiva neonatal. Prematuro. Recém-nascido de muito baixo peso. Título: Acompanhamento dos desfechos clínicos no primeiro ano de vida de prematuros.

\section{RESUMEN}

En este estudio se investigaron los resultados clínicos de los primeros años de vida en los recién nacidos prematuros dados de alta de la Unidad de Cuidados Neonatales (UCIN) de los datos de mortalidad, de la readmisión y el desarrollo motor de los niños. Se realizó un estudio retrospectivo de cohortes. La muestra consistió en 170 niños con edad gestacional inferior a 37 semanas que sobrevivieron a la hospitalización en la UCIN. Los datos se obtuvieron de los registros médicos y el hospital sistema de TI y entrevista telefónica con el cuidador. Se observó 100\% de supervivencia durante el período de estudio, el 39,4\% de los niños tenía reingresos con frecuencia (26,5\%) debido a enfermedades respiratorias. En cuanto al desarrollo, se encontró que el uso de la edad corregida se consideró como dentro de lo esperado. Al final de este estudio, se concluyó que el prematuro de los estudios mostró buena evolución clínica de observación propuesta.

Descriptores: Unidades de cuidados intensivos neonatal. Prematuro. Recién nacido de muy bajo peso. Título: Resultados clínicos en el primer año de vida del prematuro.

a Master in Nursing. R.N. at the Neonatal Hospitalization Unit at Hospital de Clínicas de Porto Alegre, Porto Alegre, RS, Brazil. b R.N. at the Emergency Unit of Ernesto Dornelles Hospital, Porto Alegre, RS, Brazil.

c Ph.D. in Epidemiology. Adjunct Professor at the School of Nursing of the Federal University of Rio Grande do Sul, Porto Alegre, RS, Brazil.

Versão on-line em Português/Inglês: http://www.scielo.br/ scielo.php?script=sci_serial\&pid=1983-1447\&lng=pt\&nrm=iso 


\section{INTRODUCTION}

Advances in neonatology in recent decades have brought great changes in the care of newborns, promoting an increase in their survival. The installation of Neonatal Intensive Care Units (NICU), the use of antenatal corticosteroids and surfactant therapy in premature newborns are advances which have contributed a lot in this sense $\mathrm{e}^{(1,2)}$. Nevertheless, the high risk for the emergence of sequelae in development remain present in babies born under extremely adverse conditions ${ }^{(3)}$.

Many newborns (NB) who have a poor prognosis for survival at birth, in fact, survive their stay in the NICU. Nevertheless, their quality of life and survival at one year may be limited due to clinical and neurological sequelae and the demand of frequent hospital readmissions ${ }^{(3,4)}$. There is also evidence of a higher incidence of severe neurological damage such as cerebral palsy, disorders and mild developmental delays among survivors, boosting the conducting of research and creating the need for more information on the development and quality of life of these children ${ }^{(2)}$.

Prematurity has been associated with increased neonatal morbidity, including among late premature infants ${ }^{(5)}$. A study regarding the morbidity and mortality of late premature infants (gestational age between 33-36 weeks), in comparison to those born at term (between $37-40$ weeks), revealed that the neonatal mortality rate was 5.5 times higher in the first group, mainly in the first week of life, with a 4.4-fold increased risk of respiratory morbidity, 5.2 times for infection, and a significantly longer period of stay when compared to full-term infants (FTI $)^{(6)}$.

Premature infants have more complications at birth such as respiratory distress syndrome, necrotizing enterocolitis, intraventricular hemorrhage, among others. More readmissions are demanded, especially due to lower respiratory tract infections secondary to immaturity of the respiratory system, vulnerable to the occurrence of deficits in lung function that can persist into adulthood ${ }^{(3,7)}$. Studies show that the infection by respiratory syncytial virus (RSV) is higher in premature infants in relation to full-term ones $^{(7,8)}$. Transient neurological abnormalities involving posture, fine and gross motor skills, coordination and balance, reflexes, and especially dystonias (hyper or hypotonia) are detected in $40-80 \%$ of cases, disappearing in the second year of life $\mathrm{e}^{(1)}$.
Researchers have been devoted to analyzing the development of children during their growth, while at pre-school and school age. Nevertheless, in the first year of life the child must acquire skills such as sitting, crawling and walking that, when absent, determine developmental delay ${ }^{(7,9)}$. A study with the aim to compare the motor development of moderately pre-term and full-term school infants, found a significant difference in motor development with an emphasis on fine motor skills which leads to a difficulty in writing, considered an essential requirement for good academic performance ${ }^{(10)}$.

Motor acquisitions in the first year of life are relevant in predicting the overall development of the child, as the period is considered as one of the most critical in child development ${ }^{(9)}$. In it, motor development has an accelerated pace of changes that culminate in the functions of mobility, with the acquisition of crawling and walking independently, at nine and 12 months of age, respectively ${ }^{(7,9)}$. Risk factors such as premature birth and low birth weight can interfere with the rhythm and the motor patterns of these acquisitions during the first year of the child's life $\mathrm{e}^{(1,3,7)}$.

The early stages of intrauterine, perinatal, postnatal life and the first year of life have garnered the interest of researchers, as these periods may provide useful information for understanding future changes in the child's development. The incidence of neurological disorders that hinder survival in appropriate conditions have not changed, despite the implementation of intensive care leading to the survival of newborn pre-term infants (PTI). Thus, as the assistance to newborn pre-term infants improves, it becomes a priority to know how the growth and development of these children behaves $^{(1,3,5)}$.

Based on the observation that PTI are characterized as the child population at higher risk for morbidity and mortality ${ }^{(1,9,6)}$, the aim of this study was to evaluate the clinical outcomes of premature infants discharged from the NICU through data related to mortality, hospital readmissions and markers of motor development of these children during the first year of life.

\section{METHODS}

This is a retrospective cohort study, whose research project was approved as regards its meth- 
odological and ethical aspects by the Research Committee of the School of Nursing at the Federal University of Rio Grande do Sul and by the Research Ethics Committee of the institution where the study was carried out (protocol number 11-0492).

Premature infants (gestational age $<37$ weeks) who were born between December 2009 and November 2010 at a teaching hospital in southern Brazil and who survived the neonatal ICU of the institution in question were included. No NB sent for adoption or to institutions for minors were included; nor NB from other institutions, since the conditions related to the perinatal period and the transport may influence the prognosis, and/or patients with complex genetic diseases and metabolic syndromes such as inherent metabolism errors, Down Syndrome (Trisomy 21).

Patients were identified through a query (worksheet extracted from a computerized patient management system at the institution, following the eligibility criteria provided by the authors). Upon completing 12 months of the child's corrected age ${ }^{(11)}$ the person responsible for the child was contacted by telephone, when the researcher identified herself and invited the adult to participate in the study. The same person carried out all telephone contacts, following a standardized checklist for interviews when the person responsible provided information on the following outcomes for the first year of the child's life: survival, hospital readmissions and signs of motor development (supporting the head, sitting and standing). Maternal data (prenatal care; single or multiple pregnancy; hypertension syndrome and diabetes; peripartum infection; antenatal corticosteroids and type of delivery) and those related to birth and hospitalization in the NICU (clinical characteristics at birth and evolution at admission) were obtained in both paper and electronic records, and supplemented by information from the child's parent/guardian, whenever necessary. To complement the information provided by them, the authors searched for information on motor development and readmissions in the institution in outpatient records.

Correction of chronological age (ChrA) for corrected gestational age (CoA) was adopted, a procedure to properly classify the child within the categories of "adequate" or "inadequate", as regards motor development, to reduce the temporary delay of the PTI until it reaches the equivalent develop- ment of the FTI. Infants considered as having the appropriate development for their age were those who, according to the statement of the person responsible and the age correction ${ }^{(10)}$ : (a) between three and six months managed to fully support the head; (b) between six and nine months sat up without support and (c) between 10 and 12 months could stand, leaning on something fixed ${ }^{(9)}$.

All data were entered into an electronic spreadsheet (Excel) and, by means of the SPSS 17.0 software, a descriptive analysis of the variables was carried out. Continuous variables were described as mean \pm standard deviation or median (interquartile range), as per their distribution, whereas categorical variables were expressed in absolute numbers (percentage).

The sample was estimated based on historical data at the institution, indicating that, during the study period, there were 476 hospitalizations of infants in the NICU, with 272 PTI, 238 of which survived. Considering a confidence interval of $95 \%$, the need for inclusion of 149 premature infants for adequate representation of the population was estimated. Given the longitudinal nature of the study and the possibility of death in the first year of life, the sample estimate was increased by $20 \%$, totaling 179 subjects.

\section{RESULTS}

During the period between December 2009 and November 2010, 4232 children were born, 514 of which were premature infants (Capurro $<37$ weeks). Among the PTI, 247 were hospitalized in the neonatal ICU for clinical complications immediately after birth. After applying the exclusion criteria, $54(22.3 \%)$ children were excluded from the study: 30 died during hospitalization in the neonatal unit, 20 due to congenital diseases and four per referral for adoption. Of the 193 subjects included, there were 23 losses: 22 because of failure in the attempt to contact by phone for interview, and one refusal to participate in the study. Thus, the sample actually analyzed 170 PTI in this study.

More than a third of the mothers (35.3\%) had completed high school, only four $(2.6 \%)$ were illiterate and more than half of them (58.3\%) classified their occupation as "housewife". Around 73\% of mothers had complications during pregnancy, with pre-eclampsia (43.0\%) and maternal infection 
Table 1 - Characteristics of the conditions of pregnancy, birth and hospitalization in the NICU. Porto Alegre, RS, December 2009 to November 2010.

\begin{tabular}{lc}
\hline \multicolumn{1}{c}{ Variables } & Total $\mathbf{n = 1 7 0}$ \\
\hline Gestational age, weeks* & $33.1 \pm 2.3$ \\
Female & $87(51.2)$ \\
Cesarean delivery & $125(73.5)$ \\
Gestational age/weight ratio & \\
$\quad$ AGA & $122(71.8)$ \\
$\quad$ SGA & $47(27.6)$ \\
LGA & $1(0.6)$ \\
Apgar score $<7$ at the first & $56(32.9)$ \\
$\quad$ Apgar score $<7$ at the fifth & $8(4.7)$ \\
Birth weight & \\
$\quad<1000 g$ & $9(4.7)$ \\
$\quad$ 1000 1 1500g & $41(22.4)$ \\
1500 2500g & $96(58.8)$ \\
$\quad \geq 2500 g$ & $24(14.1)$ \\
Procedure for resuscitation at & $113(66.5)$ \\
birth & $68(59.1)$ \\
Inhaled oxygen & $32(27.8)$ \\
Positive pressure ventilation & $15(13.1)$ \\
$\quad$ Tracheal intubation &
\end{tabular}

* Data expressed as mean \pm standard deviation. Other data expressed in percentage (\%). AGA: appropriate for gestational age; SGA: small for gestational age; LGA: large for gestational age; O2: oxygen.

(29.8\%) being the most frequent. Cesarean section was the predominant type of delivery (73.5\%). Other data characterizing the sample are shown in Table 1.

The median hospital stay after birth was 23 days, in which 110 children (64.7\%) remained hospitalized for up to 31 days. In the first year of corrected age, none of the children died within the follow-up period. Nevertheless, 67 (39.4\%) infants required hospitalization, and, of these, $43(64.2 \%)$ newborns were readmitted only once. The main reasons for readmissions are shown in Table 2.

In relation to motor development, when checking if the child could hold his head up, up to six months, when assessed by chronological age, $94.7 \%$ were in normal development for the period. By adopting the corrected age, $97.1 \%$ of children
Table 2 - Causes of re-hospitalization up to one year of corrected age. Porto Alegre, RS, December 2009 to November 2010.

\begin{tabular}{lc}
\hline \multicolumn{1}{c}{$\begin{array}{c}\text { Leading cause of } \\
\text { re-hospitalization } \mathbf{1}(\mathbf{N}=\mathbf{6 7})\end{array}$} & \% \\
\hline Respiratory causes & $48(71.6)$ \\
Surgical causes & $7(10.5)$ \\
Other causes & $7(10.5)$ \\
Gastrointestinal causes & $5(7.4)$ \\
\hline \multicolumn{1}{c}{ Leading cause of other } \\
\multicolumn{1}{c}{ readmissions $(\mathbf{N}=\mathbf{2 4})$} & $17(70.9)$ \\
\hline Respiratory causes & $3(12.5)$ \\
Surgical causes & $2(8.3)$ \\
Other causes & $2(8.3)$ \\
Gastrointestinal causes
\end{tabular}

Data expressed in $\mathrm{n}(\%)$.

had this ability. Similarly, 151 (88.8\%) children could sit up, up to nine months of chronological age and, by adopting the corrected age, 165 (97.1\%) had this appropriate development marker for their age. When assessed for the ability to stand at 12 months of chronological age, $130(76.5 \%)$ had this marker, and the performance was better when the corrected age was considered $(159$ children $=$ 93.5\%) (Figure 1).

\section{DISCUSSION}

In the present study, a favorable outcome in the first year of life was identified in a cohort of children born prematurely and hospitalized in a high complexity neonatal ICU in southern Brazil. All of the children survived the first year of corrected age, requiring readmission in less than $40 \%$ of them, which, in large part, demanded only a single hospital readmission. Furthermore, over $90 \%$ of babies showed markers of appropriate motor development for their corrected age.

The mortality data found agree with a study conducted in São Paulo ${ }^{(12)}$ in 2011, in which 130 children were monitored during the first year of life, and whose sample consisted of 46 premature infants, also with unidentified deaths. A prospective cohort study that analyzed morbidities related to prematurity ${ }^{(8)}$ conducted the follow-up of 97 pre- 


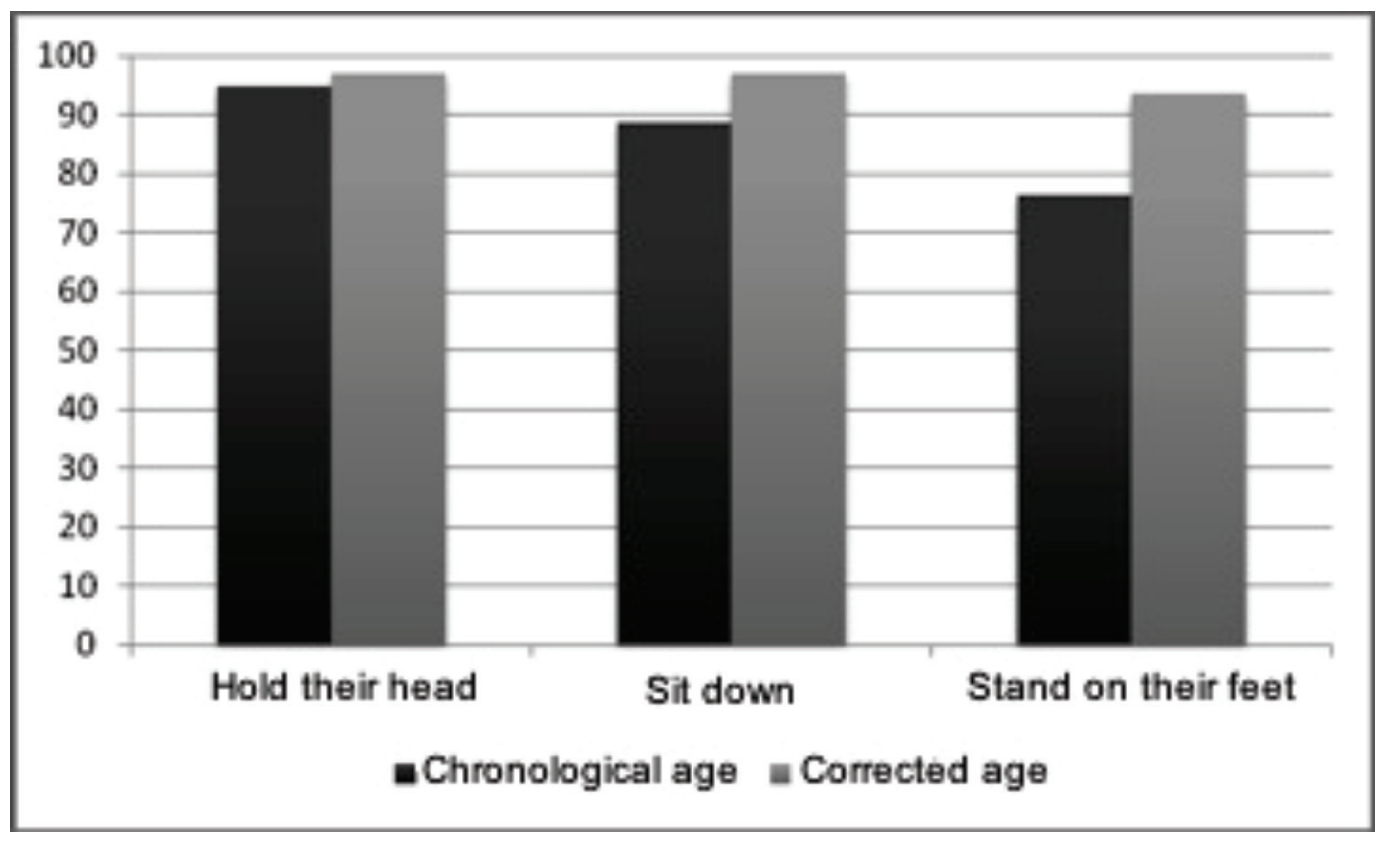

Figure 1 - Markers of motor development at 12 months of chronological age and corrected age. Data expressed in percentage (\%). N=170. Porto Alegre, RS, December 2009 to November 2010.

term infants weighing less than $1,500 \mathrm{~g}$ and with gestational age of less than 34 weeks for 12 months of corrected age and revealed that only one baby died in the period ${ }^{(8)}$. Similar data were obtained in a Canadian study conducted in $2009^{(6)}$, to monitor pre-term infants between 33 and 37 weeks for 12 months. They found that of the 6,381 children in the group of 36 pre-term infants, $36(0.6 \%)$ died before reaching one year of age ${ }^{(6)}$. Moreover, the results of a multi-center study conducted in the Netherlands in 2003, which evaluated 266 children under 32 weeks for 24 months of chronological age, identified a mortality of $10.9 \%$, with this rate being especially higher in the group of children born with less than 27 weeks. The difference in the follow-up time of children may explain the differences between the results presented by those authors and by this study. Likewise, a study that followed 53 newborn pre-term infants (gestational age $<33$ weeks) ${ }^{(4)}$, for six months, identified a mortality rate of $7.6 \%$. In the present study, 33 weeks of gestational age represented the mean age of the NB monitored. Therefore, the lower gestational age as an inclusion criterion in the referred study from Paraná(4) $^{(4)}$ could partly explain the higher mortality rate, even in a smaller follow-up time.

Proportion and reasons for re-hospitalization similar to those described in the present study were also presented in the same study ${ }^{(4)}: 30.2 \%$ of 53 neonates requiring readmissions, with $56.3 \%$ being due to respiratory conditions ${ }^{(4)}$. A study with a group of 48 children, with 24 of these being pre-term and 24 full-term, showed that 24 (100\%) children in the group of prematurely born infants required hospitalization, remaining at the institution between three and 60 days, however, the study authors did not report the causes ${ }^{(13)}$. An American, retrospective and multi-center study, reported that $45 \%$ of 3,787 children in a program monitoring the pre-term infants were hospitalized in the first year of life, especially for respiratory causes ${ }^{(14)}$. Lower rates $(15.2 \%)$ were described by another study, which examined re-hospitalizations and their causes in the first year of life of $1,683 \mathrm{NB}$ with a gestational age of $>33^{(15)}$. A likely explanation for a lower rate of re-hospitalization was that the authors monitored PTI between 33 and 36 weeks, unlike the present study, which monitored all PTI below 37 weeks.

Most of our PTI showed markers of motor development appropriate for the corrected age in the first year of life. It is worth emphasizing that it involved pre-term infants without other comorbidities. Corroborating the data presented in this follow-up, a longitudinal study of pre-term infants $<1,500 \mathrm{~g}$ and with a gestational age of $\leq 34$ weeks without neurosensory changes, selected 
from the outpatient follow-up of infants at high risk, which evaluated 143 pre-term infants in relation to ages of acquisition of all motor abilities up to independent walking and it was observed that there was no delay in motor development for corrected age in all NB in the study ${ }^{(16)}$. Nevertheless, a study conducted in Belo Horizonte ${ }^{(17)}$ compared schoolchildren who were born pre-term (under 34 weeks and 1,500 grams) and full-term, at seven years of age and identified major signs of disorders of motor coordination in the group born with younger age and less weight. Another study, conducted in Ribeirão Preto, São Paulo ${ }^{(18)}$, which evaluated 30 PTI under 1,500 grams, showed that children born with lower weight and a younger gestational age remained hospitalized for longer periods and those with adverse family situations had more developmental problems. Another study $^{(19)}$ compared a group of pre-term infants ( $\mathrm{GA} \leq 34$ weeks, $\mathrm{n}=22$ ) and a group of full-term (with $\mathrm{GA} \geq 37$ weeks, $\mathrm{n}=22$ ), all with less than 2,500 grams. The authors found no significant difference in gross motor performance between the groups, as assessed by the Alberta Infant Motor Scale (AIMS), at ages four, six and eight months ${ }^{(19)}$. It is noteworthy that the authors of the article cited did not mention whether there was chronological age correction for the corrected age.

A possible limitation of this study lies in the adoption of a retrospective design, in which the main source of data comes from a parent/guardian, subject to recall bias, which would be minimized in a prospectively collected study, with data collected directly from sources of the care provided. Nevertheless, this is an initial study to assess the potential magnitude and severity of the problem, which justifies the design adopted.

The monitoring of children discharged from the NICU by a multidisciplinary team may facilitate early identification and intervention for children who, even under corrected age, show signs of developmental delays.

\section{CONCLUSION}

In conclusion, premature infants born at the HCPA and survivors of hospitalization at the NICU during the period analyzed had a good prognosis, given the absence of deaths in the first year of life. On the other hand, many children still de- mand re-hospitalization in the first year, especially for respiratory events. It is possible to say that, in the absence of other genetic and neurological co-morbidities and adopting the corrected age in pre-term infants, a low rate is evident for delays in motor development in the first year of life.

\section{REFERENCES}

1 Rugolo LMSS. Crescimento e desenvolvimento a longo prazo do prematuro extremo. J Pedriatr. 2005;81(1):101-110.

2 Moster D, Lie RT, Markestad T. Long-term medical and social consequences of preterm birth. N Engl J Med. 2008;17(359):262-273.

3 Lawn JE, Gravett MG, Nunes TM, Rubens CE, Stanton C, GAPPS Review Group. Global report on preterm birth and stillbirth (1 of 7 ): definitions, description of the burden and opportunities to improve data. BMC Pregnancy Childbirth. 2010;10(Suppl 1): S1.

4. Hayakawa LM, Schmidt, KT, Rosseto EG, Souza SNDH, Bengozi TM. Reinternação de prematuros com muito baixo peso nascidos em um hospital universitário. Esc Anna Nery Rev Enferm. 2010;14(2):324-329.

5 McGowan JE, Alderdice FA, Homes VA, Johnston L. Early childhood development of late-preterm infants: a systematic review. Pediatrics. 2011;127(6):1111-1124.

6 Khashu M, Narayanan M, Bhargava S, Osiovich H. Perinatal outcomes associated with preterm birth at 33 to 36 weeks' gestation: a population-based cohort study. Pediatrics. 2009; 123(1):109-113.

7 Vieira MEB, Linhares MBM. Desenvolvimento e qualidade de vida em crianças nascidas pré-termo em idades pré-escolar e escolar. J Pedriatr. 2011;87(4):281-291.

8 Chalfun G, Mello RR, Dutra MVP, Andreozzi VL, Silva KS. Fatores associados à morbidade respiratória entre 12 e 36 meses de vida de crianças nascidas de muito baixo peso oriundas de uma UTI neonatal pública. Cad Saúde Pública. 2009;25(6):1399-1408.

9 Diament A. Exame neurológico do lactente. In: Diament A, Cypel S. Neurologia infantil. $5^{\mathrm{a}}$ ed. São Paulo: Atheneu; 2010. p 35-66. 
10 Camargos ACR, Fontes PLB, Araujo APS, Silva FC, Pereira LP, Souza SMF. Desenvolvimento motor de crianças pré-termo moderadas aos sete e oito anos de idade. Fisioter Pesqui. 2011;18(15):182-187.

11 American Academy of Pediatrics. Policy Statement: Age Terminology During the Perinatal Period. Pediatrics. 2004; $114(5): 1362-1364$.

12 Rodrigues OMPR; Bolsoni-Silva AT. Efeitos da prematuridade sobre o desenvolvimento de lactentes. Rev Bras Crescimento Desenvolv Hum. 2011;21(1):111-121.

13 Maia PC, Silva LP, Oliveira MMC, Cardoso MVLML. Desenvolvimento motor de crianças prematuras e a termo - uso da Alberta Infant Motor Scale. Acta Paul Enferm. 2011;24(5):670-675.

14 Ambalavanan N, Carlo WA, McDonald AS, Yao Q, Das A, Higgins RD, Generic Database and Follow-up Subcommittees of the Eunice Kennedy Shriver National Institute of Child Health and Human Development Neonatal Research Network. . Identification of extremely premature infants at high risk of rehospitalization. Pediatrics. 2011;128(5):1216-1225.
15 McLaurin KK, Hall CB, Jacson EA, Owens OV, Mahadevia PJ. Persistence of morbidity and cost differences between late-preterm and term infants during the first year of life. Pediatrics. 2009;123(2):653-659.

16 Volpi S, Rugolo LMSS, Peraçoli JC, Corrente JE. Aquisição de habilidades motoras até a marcha independente em prematuros de muito baixo peso. J Pediatr (Rio J.). 2010;86(2):143-148.

17 Magalhães, L.C.; Rezende, F.C.A; Albuquerque, P.D.R. Análise comparativa da coordenação motora de crianças nascidas a termo e pré-termo, aos 7 anos de idade. Rev Bras Saúde Matern Infant. 2009;9(3):293-300.

18 Nobre FDA. Estudo longitudinal do desenvolvimento de crianças nascidas pré-termo no primeiro ano pós-natal. Psicol: Reflex Crít. 2009;22(3):362-369.

19 Lino PFM. Desempenho motor em crianças pré-termo e a termo aos quatro, seis e oito meses de idade: estudo comparativo [dissertação]. Belo Horizonte (MG): Universidade Federal de Minas Gerais; 2008.

\author{
Author's address / Endereço do autor / \\ Dirección del autor \\ Cristiane Raupp Nunes \\ Escola de Enfermagem - Universidade Federal do \\ Rio Grande do Sul \\ Rua São Manoel, 963, Rio Branco \\ 90620-1 10, Porto Alegre, RS \\ E-mail: crisraupp@yahoo.com.br
}

Received: 18.02.2013

Approved: 13.11.2013 